\title{
Post-Transplant Hypomagnesemia in Turkish Renal Transplant Recipients: The Frequency and Related Factors
}

\author{
Aydin Unal*, Ismail Kocyigit, Feridun Kavuncuoglu, Murat Hayri Sipahioglu, Bulent Tokgoz, Oktay Oymak and Cengiz Utas \\ Department of Nephrology, Erciyes University Medical School, Kayseri, Turkey
}

\begin{abstract}
Aim: Hypomagnesemia is a frequent complication in RTRs, particularly in the early post-transplant period. Hypomagnesemia is usually associated with the use of calcineurin inhibitors. The relationship between cyclosporine use and hypomagnesemia is well known. However, it has been reported in several studies that hypomagnesemia was seen more in RTRs treated with tacrolimus compared to those treated with cyclosporine. In this study, we aimed to investigate the frequency and risk factors of post-transplant hypomagnesemia and effects of calcineurin inhibitors on hypomagnesemia among Turkish patients.
\end{abstract}

Patients and method: The study included 68 adult renal transplantation recipients. Hypomagnesemia was defined as serum magnesium level $<1.4 \mathrm{mEq} / \mathrm{L}$.

Result: Hypomagnesemia were found in $26(38.2 \%)$ of the 68 patients. Levels of serum calcium and glucose were significantly higher in hypomagnesemic group compared to normomagnesemic group $(9.7 \pm 0.5 \mathrm{mg} / \mathrm{dL} v s .8 .4 \pm 0.5$, p: 0.029 and $107.3 \pm 19.1 \mathrm{mg} / \mathrm{dL}$ vs. $95.8 \pm 16.1$, p: 0.010 , respectively). Post-transplant duration was meaningfully longer in normomagnesemic group (9.5 months vs. 46.5, p: 0.001). Serum magnesium level was meaningfully higher in patients with cyclosporine compared to patients treated with tacrolimus $(1.44 \pm 0.5 \mathrm{mEq} / \mathrm{L}$ vs. $1.52 \pm 0.2, \mathrm{p}: 0.002$, respectively). Post-transplant duration was significantly longer in cyclosporine group (12 months vs. 98.5, p: 0.001). Frequency of hypomagnesemia was significantly higher tacrolimus group ( $58 \%$ vs. $10 \%$, p: 0.001$)$.

Conclusion: The frequency of hypomagnesemia was high among Turkish renal transplant recipients, especially those treated with tacrolimus. Increased concentrations of serum calcium and glucose and the shorter post-transplant duration were risk factors for post-transplant hypomagnesemia.

Keywords: Calcineurin inhibitor; Hypomagnesemia; Post-transplant duration; Renal transplantation; Serum calcium; Serum glucose

\section{Introduction}

The early period after renal transplantation is a critical phase in terms of extracellular volume assessment, intravenous fluid administration, and electrolyte balance. The electrolyte levels including sodium, potassium, bicarbonate, calcium, phosphorus, and serum magnesium and parameters of renal function in Renal Transplant Recipients (RTRs) should be carefully examined during this period.

Hypomagnesemia is a frequent complication in RTRs, particularly in the early post-transplant period and several studies have reported that hypomagnesemia was detected in 10 to $26 \%$ of renal transplant recipients [1,2]. Hypomagnesemia is usually associated with the use of calcineurin inhibitors, which are used to prevent transplant rejection $[3,4]$. The relationship between cyclosporine use and hypomagnesemia is well known. However, it has been reported in several studies that hypomagnesemia was seen more in RTRs treated with tacrolimus compared to those treated with cyclosporine $[5,6]$.

In the present study, we aimed to examine the frequency and risk factors of post-transplant hypomagnesemia and the effect of calcineurin inhibitors on hypomagnesemia in Turkish patients.

\section{Patients and Method}

The cross-sectional study included 68 adult stable RTRs. Patients who had acute allograft rejection, acute infection with bacteria, viral (including cytomegalovirus) or fungal, as well as requiring dialysis were excluded. Hepatitis B virus was detected in 3 patients, who had normal transaminase levels. Similarly, hepatitis $\mathrm{C}$ virus was detected in 3 patients. Two of the patients had normal transaminase levels while another patient had mild elevated transaminase levels. Five patients had mild elevated transaminase levels.
Cause of elevation in the transaminase levels was drug-induced injury in 3 patients, hepatitis $\mathrm{C}$ virus in 1 patient, and steatohepatitis in 1 patient.

We recorded levels of serum magnesium, creatinine, sodium, potassium, calcium, phosphorus, uric acid, alkaline phosphatase, glucose, albumin, hemoglobin, intact parathormone (iPTH), and amount of proteinuria and 24 hour urine volume, body weight and height at the last follow-up. We also noted demographic data such as age and gender, cause of ESRD, immunosuppressive regimen, allograft source, and duration after transplantation. Levels of tacrolimus and cyclosporine were evaluated by the T0 level and C2 level, respectively. There was no cross-over between tacrolimus and cyclosporine during the previous course of the transplantation. Creatinine clearance was determined from 24-hour collected urine samples. Hypomagnesemia was defined as a serum magnesium level $<1.4 \mathrm{mEq} / \mathrm{L}$. Fractional excretion of magnesium (FEMg) was calculated using the formula: (urine magnesium $\times$ plasma creatinine/plasma magnesium $\times$ urine creatinine $) \times 100$. Fractional excretion of sodium $(\mathrm{FENa})$ was calculated

${ }^{*}$ Corresponding author: Dr. Aydin Unal, MD, Department of Nephrology, Erciyes University Medical School, Organ Transplant and Dialysis Hospital, 38039, Kayseri, Turkey, Tel: 90-3524374937; Fax: 90-3524375807; E-mail: a.unal@erciyes.edu.tr aydinunal2003@gmail.com

Received November 16, 2012; Accepted December 28, 2012; Published December 31, 2012

Citation: Unal A, Kocyigit I, Kavuncuoglu F, Sipahioglu MH, Tokgoz B, et al. (2013) Post-Transplant Hypomagnesemia in Turkish Renal Transplant Recipients: The Frequency and Related Factors. J Nephrol Therapeut S11: 002. doi:10.4172/2161. 0959.S11-002

Copyright: (c) 2013 Unal A, et al. This is an open-access article distributed under the terms of the Creative Commons Attribution License, which permits unrestricted use, distribution, and reproduction in any medium, provided the original author and source are credited. 
Citation: Unal A, Kocyigit I, Kavuncuoglu F, Sipahioglu MH, Tokgoz B, et al. (2013) Post-Transplant Hypomagnesemia in Turkish Renal Transplant Recipients: The Frequency and Related Factors. J Nephrol Therapeut S11: 002. doi:10.4172/2161-0959.S11-002

Page 2 of 5

using the formula: (urine sodium $\times$ plasma creatinine/plasma sodium $\times$ urine creatinine $) \times 100$.

Post-transplant hypertension was defined as resting blood pressure was $\geq 140 \mathrm{mmHg}$ systolic and/or $90 \mathrm{mmHg}$ diastolic or participants were receiving antihypertensive treatment. Post-transplant diabetes mellitus was described as the fasting blood glucose level was $\geq 126 \mathrm{mg} /$ $\mathrm{dL}$ or 2 -hour glucose level was $\geq 200 \mathrm{mg} / \mathrm{dl}$ in oral glucose tolerance test or participants were receiving hypoglycemic treatment such as insulin or oral antidiabetic drug.

\section{Statistical analysis}

SPSS 15.0 statistical software was used for all analysis. Continuous variables with normal distribution were presented as mean \pm standard deviation. The median value was used when normal distribution was absent. Statistical analysis of the parametric variables between two groups was performed by the Student's $t$ test. The Mann-Whitney U test was used to compare nonparametric variables between two groups. The correlation analysis was evaluated by the Pearson's correlation test for parametric variables and by the Spearman's correlation test for nonparametric variables. Qualitative variables were given as percentages and the correlation between categorical variables was examined by the chi-square test and Fisher's exact test. A P value of $<0.05$ was considered to be significant.

\section{Results}

The characteristics of the 68 RTRs are summarized in table 1 . The mean age of the 68 patients was $38.0 \pm 10.4$ years; 51 of the patients were male and the rest were female. Living donors were the major source of allograft. The cause of ESRD was not known in most patients. Hemodialysis was chosen as the main renal replacement treatment modality before renal transplantation. The median duration after transplantation was 24 (1-252) months. The mean creatinine clearance of the 68 patients was $66.3 \pm 28.5 \mathrm{~mL} / \mathrm{min}$. Post-transplant diabetes mellitus and hypertension were observed in $8(11.3 \%)$ and $56(78.9 \%)$, respectively. Ten (14.1\%) patients had history of an acute allograft refection.

Hypomagnesemia was detected in 26 (38.2\%) of the 68 patients. Table 2 shows a comparison of demographic, clinical, and laboratory parameters between the hypomagnesemic and normomagnesemic patients. The serum magnesium level was significantly lower in the hypomagnesemic group than in the normomagnesemic group, whereas levels of serum calcium and glucose, the values of creatinine clearance and systolic and diastolic pressure were significantly higher in the hypomagnesemic group compared to the normomagnesemic group. On the other hand, duration after transplantation was meaningfully longer in the normomagnesemic group than in the hypomagnesemic group. None of hypomagnesemic patients had history of an acute allograft refection while it was observed in 10 of normomagnesemic patients. However, there was no significant difference between the two groups with regard to age, gender, source of allograft, Body Mass Index (BMI), use of Angiotensin Converting Enzyme Inhibitors (ACEI) or Angiotensin II Receptor Blockers (ARB) and vitamin $\mathrm{D}$, concentrations of serum sodium, potassium, phosphorus, uric acid, alkaline phosphatase, albumin, hemoglobin, and iPTH, FEMg and FENa values, presence of post-transplant diabetes mellitus and hypertension, and amount of proteinuria and 24 -h urine volume.

Table 3 demonstrates a comparison of demographic, clinical, and laboratory parameters between patients treated with tacrolimus and those treated with cyclosporine. Mycophenolate and azathioprine were the major concomitant immunosuppressive agents used in the tacrolimus and cyclosporine groups, respectively. There was no significant difference between the two groups with regard to the use of steroids. Serum magnesium level and age were meaningfully higher in patients treated with cyclosporine compared to patients treated with tacrolimus. Similarly, duration after transplantation was significantly longer in the cyclosporine group than in the tacrolimus group. On the other hand, the prevalence of hypomagnesemia and serum albumin concentration were significantly higher in patients treated with tacrolimus. However, there was no significant difference between the tacrolimus and cyclosporine groups in terms of gender, source of allograft, BMI, use of ACEI or ARB and vitamin D, concentrations of serum sodium, potassium, calcium, phosphorus, uric acid, glucose, hemoglobin, and iPTH, FEMg and FENa values, creatinine clearance, systolic and diastolic blood pressure, presence of post-transplant diabetes mellitus and hypertension, history of acute allograft rejection and amount of proteinuria and 24-h urine volume.

Comparison of clinical and laboratory parameters, which adjusted for duration after transplantation, between patients treated with tacrolimus and those treated with cyclosporine is presented in table 4. There was no difference between two groups with regard to all parameters including levels of serum magnesium and albumin.

The serum magnesium level inversely correlated with serum glucose level (Figure 1) and creatinine clearance value (Figure 1). On the other hand, it correlated with duration after transplantation (Figure

\begin{tabular}{|l|c|}
\hline Age (year) & $38.0 \pm 10.4$ \\
\hline Male/Female & $51(75 \%) / 17(25 \%)$ \\
\hline Type of donor (deceased/living) & $24(35.3 \%) / 44(64.7 \%)$ \\
\hline Cause of end-stage renal disease & $9(13.2 \%)$ \\
\hline Glomerulonephritis & $5(7.4 \%)$ \\
\hline Obstructive uropathy/chronic pyelonephritis & $2(2.9 \%)$ \\
\hline ADPKD & $2(2.9 \%)$ \\
\hline Hypertension & $3(4.4 \%)$ \\
\hline Others & $47(69.1 \%)$ \\
\hline Unknown & \\
\hline Type of dialysis & $42 / 27$ \\
\hline Hemodialysis/Peritoneal dialysis & $26(8-108)$ \\
\hline Duration of dialysis (mo) & $24(5-240)$ \\
\hline Hemodialysis & $24(1-252)$ \\
\hline Peritoneal dialysis & $128 \pm 16$ \\
\hline Post-transplant duration (mo) & $88 \pm 14$ \\
\hline Systolic blood pressure (mmHg) & $8(11.3 \%)$ \\
\hline Diastolic blood pressure (mmHg) & $56(78.9 \%)$ \\
\hline Presence of post-transplant diabetes mellitus & $10(14.7 \%)$ \\
\hline Presence of post-transplant hypertension & $66.3 \pm 28.5$ \\
\hline History of acute allograft rejection & $20(29.4 \%)$ \\
\hline Creatinine clearance (mL/min) & $67(98.5 \%)$ \\
\hline Use of & $20(29.4 \%)$ \\
\hline Steroid & $50(73.5 \%)$ \\
\hline Tacrolimus & $13(19.1 \%)$ \\
\hline Cyclosporine & $6(8.8 \%)$ \\
\hline Mycophenolate & $21(30.9 \%)$ \\
\hline Azathioprine & $20.3 \%)$ \\
\hline Sirolimus & \\
\hline ACEl or ARB & \\
\hline Vitamin D & \\
\hline ADPKD: Autosoma & \\
\hline
\end{tabular}

ADPKD: Autosomal-Dominant Polycystic Kidney Disease; ACEI: Angiotensin Converting Enzyme İnhibitor; ARB: Angiotensin II Receptor Blocker

Table 1: Patient characteristics $(n=68)$. 
Citation: Unal A, Kocyigit I, Kavuncuoglu F, Sipahioglu MH, Tokgoz B, et al. (2013) Post-Transplant Hypomagnesemia in Turkish Renal Transplant Recipients: The Frequency and Related Factors. J Nephrol Therapeut S11: 002. doi:10.4172/2161-0959.S11-002

\begin{tabular}{|c|c|c|c|}
\hline & $\begin{array}{l}\text { Hypomagnesemic } \\
\text { group (n: } 26)\end{array}$ & $\begin{array}{l}\text { Normomagnesemic } \\
\text { group }(n=42)\end{array}$ & $\begin{array}{l}P \\
\text { value }\end{array}$ \\
\hline Age (year) & $36.3 \pm 9.3$ & $39.2 \pm 10.9$ & 0.268 \\
\hline Gender (male/female) & $19 / 7$ & $32 / 10$ & 0.495 \\
\hline $\begin{array}{l}\text { Source of allograft (living/ } \\
\text { deceased) }\end{array}$ & $15 / 11$ & $29 / 13$ & 0.244 \\
\hline Body mass index $\left(\mathrm{kg} / \mathrm{m}^{2}\right)$ & $27.0 \pm 4.8$ & $25.0 \pm 3.4$ & 0.070 \\
\hline $\begin{array}{l}\text { Follow-up duration after } \\
\text { transplantation }(\mathrm{mo})\end{array}$ & $9.5(1-132)$ & $46.5(1-252)$ & 0.001 \\
\hline Use of ACEI or ARB & $9(34.6 \%)$ & $12(28.6 \%)$ & 0.397 \\
\hline Use of vitamin D & $9(34.6 \%)$ & $11(26.2 \%)$ & 0.318 \\
\hline $\begin{array}{l}\text { Systolic blood pressure } \\
(\mathrm{mmHg})\end{array}$ & $134 \pm 18$ & $125 \pm 15$ & 0.026 \\
\hline $\begin{array}{l}\text { Diastolic blood pressure } \\
(\mathrm{mmHg})\end{array}$ & $93 \pm 13$ & $85 \pm 14$ & 0.018 \\
\hline $\begin{array}{l}\text { Presence of post-transplant } \\
\text { diabetes mellitus }\end{array}$ & $3(11.5 \%)$ & $5(11.9 \%)$ & 0.641 \\
\hline $\begin{array}{l}\text { Presence of post-transplant } \\
\text { hypertension }\end{array}$ & $21(80.8 \%)$ & $35(83.3)$ & 0.516 \\
\hline $\begin{array}{l}\text { History of acute allograft } \\
\text { rejection }\end{array}$ & - & $10(23.8 \%)$ & 0.005 \\
\hline Serum magnesium (mEq/L) & $1.21 \pm 0.12$ & $1.68 \pm 0.48$ & 0.001 \\
\hline Serum sodium (mEq/L) & $137.5 \pm 2.9$ & $137.4 \pm 4.0$ & 0.861 \\
\hline Serum potassium (mEq/L) & $4.1 \pm 0.4$ & $4.2 \pm 0.4$ & 0.418 \\
\hline Serum calcium (mg/dL) & $9.7 \pm 0.5$ & $8.4 \pm 0.5$ & 0.029 \\
\hline Serum phosphorus (mg/dL) & $3.0 \pm 1.0$ & $3.3 \pm 0.8$ & 0.271 \\
\hline Serum uric acid (mg/dL) & $6.5 \pm 1.5$ & $6.8 \pm 1.5$ & 0.321 \\
\hline Alkaline phosphatase (IU/L) & $84(40-169)$ & $81.5(36-535)$ & 0.700 \\
\hline Serum glucose (mg/dL) & $107.3 \pm 19.1$ & $95.8 \pm 16.1$ & 0.010 \\
\hline Serum albumin (g/dL) & $4.1 \pm 0.4$ & $3.9 \pm 0.5$ & 0.194 \\
\hline Hemoglobin (g/dL) & $14.0 \pm 1.8$ & $13.5 \pm 1.9$ & 0.260 \\
\hline Intact parathormon (pg/mL) & $65(13-532)$ & $83(5-834)$ & 0.253 \\
\hline $\begin{array}{l}\text { Fractional excretion of sodium } \\
(\%)\end{array}$ & $1.3(0.5-3.0)$ & $1.5(0.5-5.5)$ & 0.303 \\
\hline $\begin{array}{l}\text { Fractional excretion of } \\
\text { magnesium }(\%)\end{array}$ & $6.5 \pm 2.5$ & $7.1 \pm 4.4$ & 0.492 \\
\hline Creatinine clearance $(\mathrm{mL} / \mathrm{min})$ & $79.3 \pm 30.0$ & $58.3 \pm 24.2$ & 0.002 \\
\hline Amount of proteinuria $(\mathrm{mg} / \mathrm{d})$ & $55(0-1130)$ & $125(0-1880)$ & 0.322 \\
\hline $\begin{array}{l}\text { Amount of 24-h urine volume } \\
(\mathrm{mL})\end{array}$ & $3416 \pm 1078$ & $3450 \pm 1207$ & 0.908 \\
\hline
\end{tabular}

ACEI: Angiotensin Converting Enzyme Inhibitor; ARB: Angiotensin II Receptor Blocker

Table 2: Comparison of demographic, clinical, and laboratory parameters between hypomagnesemic patients and normomagnesemic patients.

1). However, it did not correlate with age, levels of tacrolimus or cyclosporine, concentrations of serum calcium, phosphorus, uric acid, alkaline phosphatase, albumin, hemoglobin, and iPTH, FEMg and FENa values, amount of proteinuria and 24-h urine volume ( $\mathrm{p}>0.05)$.

\section{Discussion}

In the present study, we found that the prevalence of post-transplant hypomagnesemia was quite high. Similarly, Navaneethan et al. [7] observed that $43 \%$ of 41 RTRs in their study were hypomagnesemic. On the other hand, in another study performed in 157 RTRs treated with cyclosporine, hypomagnesemia was detected in only $16(10.2 \%)$ patients [2]. Al-Ibrahim et al. [8] found that five (11.6\%) of 43 children, who received kidney allograft, had significant hypomagnesemia. The varied prevalence of post-transplant hypomagnesemia in different studies was probably related to differences in the definition of posttransplant hypomagnesemia, mean creatinine clearance, and mean follow-up time, type of immunosuppressive protocols and ethnic and geographical factors.
A relationship between magnesium deficiency and diabetes mellitus has been reported [9-11]. Nadler et al. [9] showed that magnesium deficiency increases urinary thromboxane concentration and enhances angiotensin-induced aldosterone synthesis and suggested that magnesium deficiency produces insulin resistance. In addition,

\begin{tabular}{|c|c|c|c|}
\hline & $\begin{array}{l}\text { Tacrolimus } \\
\text { group }(n=41)\end{array}$ & $\begin{array}{l}\text { Cyclosporine } \\
\text { group }(n=20)\end{array}$ & $P$ value \\
\hline Age (year) & $35.1 \pm 8.0$ & $44.8 \pm 11.7$ & 0.001 \\
\hline Gender (male/female) & $32 / 9$ & $14 / 6$ & 0.351 \\
\hline Source of allograft (living/deceased) & $24 / 17$ & $14 / 6$ & 0.281 \\
\hline Body mass index $\left(\mathrm{kg} / \mathrm{m}^{2}\right)$ & $26.5 \pm 4.4$ & $24.9 \pm 3.7$ & 0.147 \\
\hline Duration after transplantation $(\mathrm{mo})$ & $12(1-105)$ & $98.5 \pm(5-252)$ & 0.001 \\
\hline Use of ACEI or ARB & $12(29.3 \%)$ & $7(35.0 \%)$ & 0.432 \\
\hline Use of vitamin D & $11(26.8 \%)$ & $9(45.0 \%)$ & 0.130 \\
\hline Use of steroid & $40(97.6 \%)$ & $20(100 \%)$ & 0.672 \\
\hline Use of mycophenolate & $36(87.8 \%)$ & $9(45.0 \%)$ & 0.001 \\
\hline Use of azathioprine & $4(9.8 \%)$ & $8(40.0 \%)$ & 0.008 \\
\hline Systolic blood pressure (mmHg) & $131 \pm 18$ & $124 \pm 13$ & 0.129 \\
\hline Diastolic blood pressure $(\mathrm{mmHg})$ & $90 \pm 14$ & $84 \pm 14$ & 0.142 \\
\hline Serum magnesium (mEq/L) & $1.44 \pm 0.5$ & $1.52 \pm 0.2$ & 0.002 \\
\hline Presence of hypomagnesemia & $24(58 . \%)$ & $2(10 \%)$ & 0.001 \\
\hline Serum sodium (mEq/L) & $138 \pm 3$ & $137 \pm 5$ & 0.309 \\
\hline Serum potassium (mEq/L) & $4.2 \pm 0.3$ & $4.3 \pm 0.4$ & 0.179 \\
\hline Serum calcium (mg/dL) & $9.6 \pm 0.5$ & $9.4 \pm 0.6$ & 0.164 \\
\hline Serum phosphorus (mg/dL) & $3.0 \pm 1.0$ & $3.3 \pm 0.6$ & 0.239 \\
\hline Serum uric acid (mg/dL) & $6.5 \pm 1.4$ & $7.1 \pm 1.6$ & 0.321 \\
\hline Serum glucose $(\mathrm{mg} / \mathrm{dL})$ & $102.8 \pm 19.6$ & $98.8 \pm 15.7$ & 0.429 \\
\hline Serum albumin $(\mathrm{g} / \mathrm{dL})$ & $4.0 \pm 0.5$ & $3.8 \pm 0.4$ & 0.041 \\
\hline Hemoglobin $(\mathrm{g} / \mathrm{dL})$ & $13.9 \pm 2.0$ & $13.5 \pm 1.9$ & 0.440 \\
\hline Intact parathormon (pg/mL) & $75(4.8-532)$ & $76(12-834)$ & 0.951 \\
\hline Fractional excretion of sodium (\%) & $1.3(0.5-4.5)$ & $1.6(0.5-5)$ & 0.499 \\
\hline $\begin{array}{l}\text { Fractional excretion of magnesium } \\
(\%)\end{array}$ & $6.9 \pm 3.8$ & $6.5 \pm 3.3$ & 0.675 \\
\hline Creatinine clearance $(\mathrm{mL} / \mathrm{min})$ & $71.7 \pm 27.9$ & $60.4 \pm 25.2$ & 0.130 \\
\hline Amount of proteinuria (mg/d) & $54(0-1130)$ & $157(0-1880)$ & 0.186 \\
\hline Amount of $24-h$ urine volume $(\mathrm{mL})$ & $3415 \pm 1120$ & $3519 \pm 1224$ & 0.749 \\
\hline
\end{tabular}

ACEl: angiotensin converting enzyme inhibitor, ARB: angiotensin II receptor blocker

Table 3: Comparison of demographic, clinical, and laboratory parameters between patients treated with tacrolimus and those treated with cyclosporine

\begin{tabular}{|l|c|c|c|}
\hline & $\begin{array}{c}\text { Tacrolimus } \\
\text { group }(\mathbf{n = 4 1})\end{array}$ & $\begin{array}{c}\text { Cyclosporine } \\
\text { group }(\mathbf{n = 2 0})\end{array}$ & P value \\
\hline Body mass index $\left(\mathrm{kg} / \mathrm{m}^{2}\right)$ & $26.4 \pm 0.7$ & $25.1 \pm 1.1$ & 0.384 \\
\hline Serum magnesium (mEq/L) & $1.44 \pm 0.1$ & $1.52 \pm 0.1$ & 0.630 \\
\hline Serum sodium (mEq/L) & $138 \pm 0.6$ & $136 \pm 1$ & 0.173 \\
\hline Serum potassium (mEq/L) & $4.2 \pm 0.1$ & $4.4 \pm 0.1$ & 0.170 \\
\hline Serum calcium (mg/dL) & $9.5 \pm 0.1$ & $9.5 \pm 0.1$ & 0.897 \\
\hline Serum phosphorus (mg/dL) & $3.1 \pm 0.2$ & $3.1 \pm 0.2$ & 0.824 \\
\hline Serum uric acid (mg/dL) & $6.6 \pm 0.2$ & $6.9 \pm 0.4$ & 0.627 \\
\hline Serum glucose (mg/dL) & $103 \pm 3$ & $98 \pm 5$ & 0.485 \\
\hline Serum albumin (g/dL) & $4.0 \pm 0.1$ & $3.8 \pm 0.1$ & 0.126 \\
\hline Hemoglobin (g/dL) & $14.0 \pm 0.3$ & $13.5 \pm 0.5$ & 0.453 \\
\hline Intact parathormon (pg/mL) & $127 \pm 27$ & $147 \pm 42$ & 0.719 \\
\hline Fractional excretion of sodium (\%) & $1.5 \pm 0.15$ & $1.7 \pm 0.2$ & 0.574 \\
\hline Fractional excretion of magnesium (\%) & $7.4 \pm 0.6$ & $5.5 \pm 0.1$ & 0.120 \\
\hline Creatinine clearance (mL/min) & $68.3 \pm 4.5$ & $67.5 \pm 7.0$ & 0.936 \\
\hline Amount of 24-h urine volume (mL) & $3258 \pm 198$ & $3840 \pm 308$ & 0.153 \\
\hline
\end{tabular}

Table 4: Comparison of clinical and laboratory parameters, which adjusted fo duration after transplantation, between patients treated with tacrolimus and those treated with cyclosporine. 

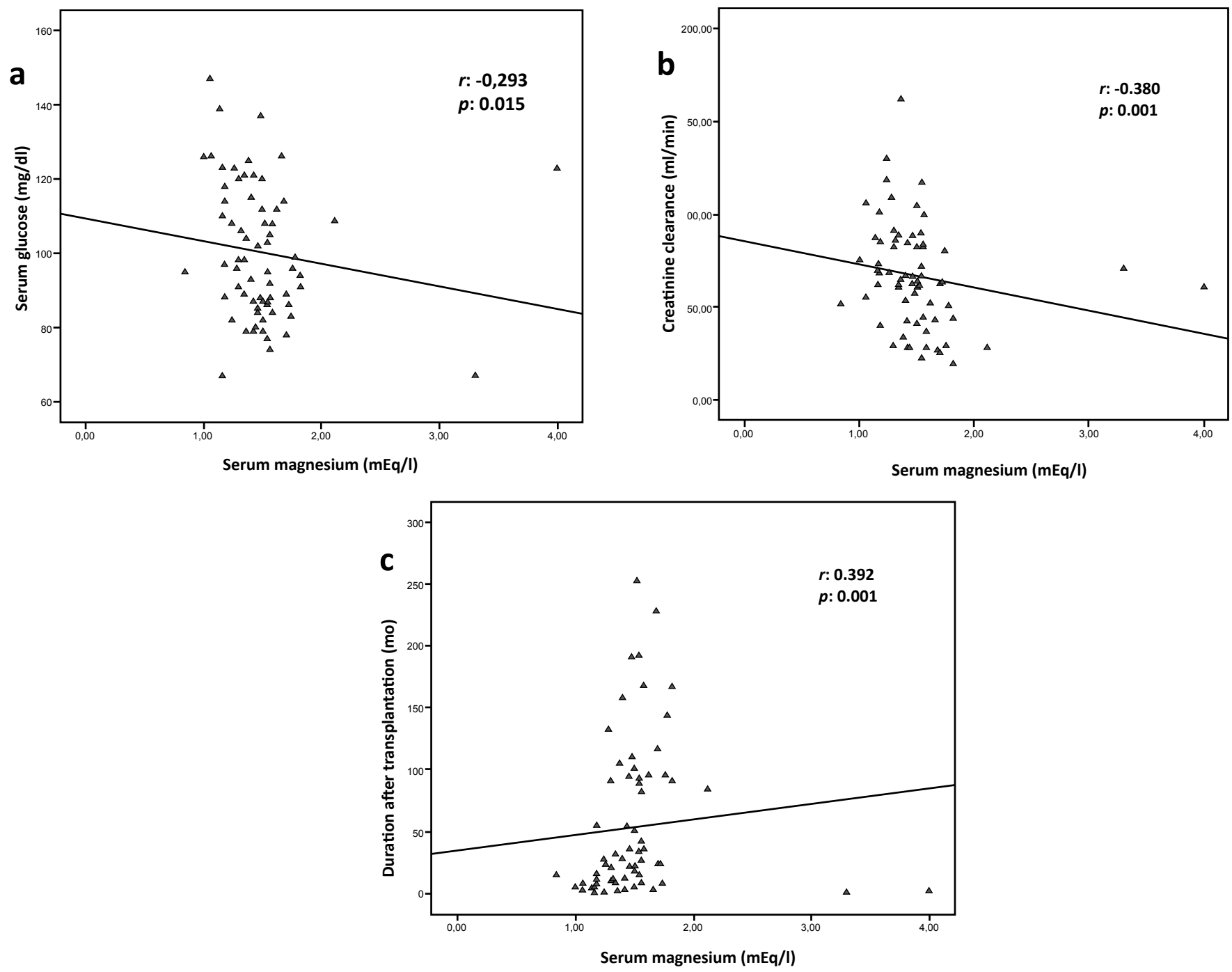

Figure 1: Relationships between serum magnesium level and serum glucose concentration (a), creatinine clearance value (b), and follow-up duration after transplantation (c)

oral magnesium supplementation improves insulin sensitivity both in diabetic patients and non-diabetic patients with insulin resistance $[10,11]$. Interestingly, a study carried out by Van Laecke et al. [12] in patients with kidney transplantation showed that magnesium levels were significantly lower in patients with new-onset post-transplant diabetes mellitus compared to those without the disorder, and patients with lower magnesium levels showed more rapid development of posttransplant diabetes mellitus. They concluded that hypomagnesemia was an independent predictor of new-onset post-transplant diabetes mellitus. Similarly, we observed that serum glucose concentration was significantly higher in patients with hypomagnesemia compared to normomagnesemic patients and there was an inverse relation between serum magnesium and serum glucose.

Hypomagnesemia is a frequent complication in patients with renal allograft, especially in the early post-transplant period [12]. On the other hand, post-transplant hypomagnesemia improves over time. In cyclosporine-treated RTRs, Ramos et al. observed that there was a significant linear trend for improvement in the serum magnesium level overtime $(1.6 \pm 0.3,1.7 \pm 0.2$, and $1.8 \pm 0.2 \mathrm{mg} / \mathrm{dl}$ at 1,3 , and 6 months after kidney transplantation, respectively). Furthermore, they detected that with time FEMg showed a decreasing trend although there was no statistically significant difference and they suggested that the hypomagnesemia was the result of urinary magnesium wasting [13]. Similarly, in the present study, duration after transplantation was very significantly shorter in the hypomagnesemic group. In addition, the serum magnesium level correlated with duration after transplantation. Hypomagnesemia may be the result of urinary magnesium wasting. Unfortunately, this theory could not be tested in this study since there was no control group. With the same FEMg, a declining Glomerular Filtration Rate (GFR) could, with time, lead to decrease in the absolute loss of magnesium in urine despite the unchanged FEMg, which corrects for changes in GFR. Similarly, in this study, we found a statistically significant decrease in creatinine clearance from 79.3 to $58.3 \mathrm{ml} / \mathrm{min}$ between the hypomagnesemic and the normomagnesemic groups.

An elevated ionized calcium concentration directly induces renal magnesium wasting and hypomagnesemia. This condition occurs most clearly in hypercalcemia due to malignant bone metastases. In hyperparathyroidism, hypercalcemia-induced renal magnesium wasting is countered by $\mathrm{PTH}$, which stimulates renal magnesium reabsorption, so renal magnesium handling is generally normal and 
Citation: Unal A, Kocyigit I, Kavuncuoglu F, Sipahioglu MH, Tokgoz B, et al. (2013) Post-Transplant Hypomagnesemia in Turkish Renal Transplant Recipients: The Frequency and Related Factors. J Nephrol Therapeut S11: 002. doi:10.4172/2161-0959.S11-002

Page 5 of 5

hypomagnesemia is rare [14]. In the present study, serum calcium levels were significantly higher in hypomagnesemic patients than in normomagnesemic patients. This possibly resulted from the former mechanism because there was no significant difference between the two groups in terms of iPTH levels.

Hypomagnesemia with renal magnesium wasting is a common complication in RTRs treated with calcineurin inhibitors [15,16]. Cyclosporine-induced hypomagnesemia appears to be related to the inhibited reabsorption of magnesium from the renal tubules via reduction in the expression of transient receptor potential melastin 6 (TRPM6) [17]. In one clinical study, hypomagnesemia was more frequent in patients treated with tacrolimus compared to those who received cyclosporine [6]. Furthermore, Higgins et al. [5] showed that serum magnesium levels in patients with renal transplantation increased significantly after conversion from tacrolimus to cyclosporine. We observed that serum magnesium concentration was significantly lower in patients who received tacrolimus compared to those treated with cyclosporine, and hypomagnesemia was significantly more prevalent in the tacrolimus group than in the cyclosporine group. On the other hand, when serum magnesium level adjusted for duration after transplantation, there was no difference between two groups with regard to it. In other words, it is possible that hypomagnesemia may be an early outcome of the use of either calcineurin inhibitor, regardless of the agent used. It may be the result of urinary magnesium wasting. With the same FEMg, a declining GFR could, with time, lead to a decrease in the absolute magnesium loss in urine despite the unchanged FEMg. Unfortunately, this study could not confirm the statistical significance of a clear numerical decrease in GFR from 71.7 to $60.4 \mathrm{ml} / \mathrm{min}$ between the tacrolimus and the cyclosporine groups. This perhaps resulted from a high standard deviation and with a larger series it might have been possible to determine statistical significance.

The route of magnesium administration depends on the severity of the clinical findings of hypomagnesemia. In severe cases such as a patient suspected of having hypomagnesemic-hypokalemic arrhythmia or a hypocalcemic-hypomagnesemic patient with tetany, intravenous magnesium replacement should be preferred [18]. On the other hand, in the asymptomatic patients, oral magnesium repletion should be given. None of our patients had severe symptomatic hypomagnesemia. We started oral replacement with magnesium citrate in hypomagnesemic patients and continued until hypomagnesemia improve. If the patient use a thiazide or loop diuretic, they also discontinued.

In conclusion, the frequency of hypomagnesemia was high among Turkish renal transplant recipients, especially those treated with tacrolimus. Increased concentrations of serum calcium and glucose and the shorter duration after transplantation were risk factors for post-transplant hypomagnesemia.

\section{Limitations}

1. The number of patients in the study was relatively low. However, the number of patients was also low in studies, in which hypomagnesemia was investigated in patients with renal transplantation, in the literature. The matter will be evaluated in future multicenter studies.

2. There was no control group. The inclusion of a control group is important in the evaluation of urinary magnesium wasting.

3. The study was cross-sectional. The matter will be evaluated by a future study in Turkish RTRs, in which will examine differences in serum magnesium levels and FEMg over time.

\section{References}

1. Mazzaferro S, Barberi S, Scarda A, Pasquali M, Rubino F, et al. (2002) Ionised and total serum magnesium in renal transplant patients. J Nephrol 15: 275-280.

2. Ahmadi F, Naseri R, Lessan-Pezeshki M (2009) Relation of magnesium level to cyclosporine and metabolic complications in renal transplant recipients. Saudi J Kidney Dis Transpl 20: 766-769.

3. Barton CH, Vaziri ND, Martin DC, Choi S, Alikhani S (1987) Hypomagnesemia and renal magnesium wasting in renal transplant recipients receiving cyclosporine. Am J Med 83: 693-699.

4. Kim HJ, Ahn YH, Kee CS, Lee KS, Kwak JY (1994) Early short-term profile of serum magnesium concentration in living donor renal transplant recipients on cyclosporine. Transplant Proc 26: 2178-2180.

5. Higgins RM, Hart P, Lam FT, Kashi H (2000) Conversion from tacrolimus to cyclosporin in stable renal transplant patients: safety, metabolic changes, and pharmacokinetic comparison. Transplantation 70: 199-202.

6. Margreiter R; European Tacrolimus vs Ciclosporin Microemulsion Renal Transplantation Study Group (2002) Efficacy and safety of tacrolimus compared with ciclosporin microemulsion in renal transplantation: a randomised multicentre study. Lancet 359: 741-746.

7. Navaneethan SD, Sankarasubbaiyan S, Gross MD, Jeevanantham V, Monk RD (2006) Tacrolimus-associated hypomagnesemia in renal transplant recipients. Transplant Proc 38: 1320-1322.

8. Al-Ibrahim A, Sanjed S, Al-Abbad A, Al-Sabban E, Al-Shaibani K (2004) Post renal transplantation tubulopathies in children: a 9-year experience at a tertiary care centre. Saudi J Kidney Dis Transpl 15: 27-33.

9. Nadler JL, Buchanan T, Natarajan R, Antonipillai I, Bergman R, et al. (1993) Magnesium deficiency produces insulin resistance and increased thromboxane synthesis. Hypertension 21: 1024-1029.

10. Rodríguez-Morán M, Guerrero-Romero F (2003) Oral magnesium supplementation improves insulin sensitivity and metabolic control in type 2 diabetic subjects: a randomized double-blind controlled trial. Diabetes Care 26 : $1147-1152$.

11. Guerrero-Romero F, Tamez-Perez HE González-González G SalinasMartínez AM, Montes-Villarreal J, et al. (2004) Oral magnesium supplementation improves insulin sensitivity in non-diabetic subjects with insulin resistance. A double-blind placebo-controlled randomized trial. Diabetes Metab 30: 253-258.

12. Van Laecke S, Van Biesen W, Verbeke F, De Bacquer D, Peeters $P$, et al. (2009) Posttransplantation hypomagnesemia and its relation with immunosuppression as predictors of new-onset diabetes after transplantation. Am J Transplant 9 : 2140-2149.

13. Ramos EL, Barri YM, Kubilis P, Peterson JC, Pfaff WW, et al. (1995) Hypomagnesemia in renal transplant patients: improvement over time and association with hypertension and cyclosporine levels. Clin Transplant 9: 185189.

14. Pollak MR, Yu ASL, Taylor EN (2008) Disorders of calcium, magnesium, and phosphate balance: Brenner and Rectors's the kidney. (8thedn), Saunders Elsevier, Philadelphia.

15. Mazzola BL, Vannini SD, Truttmann AC, von Vigier RO, Wermuth B, et a (2003) Long-term calcineurin inhibition and magnesium balance after renal transplantation. Transplant Int 16: 76-81.

16. Nawaz SH, Zafar MN, Naqvi SA, Rizvi SA (2005) Impact of cyclosporin immunosuppression on serum magnesium and its fractional excretion in renal transplant recipients. J Pak Med Assoc 55: 98-100.

17. Ikari A, Okude C, Sawada H, Takahashi T, Sugatani J, et al. (2008) Downregulation of TRPM6-mediated magnesium influx by cyclosporin A. Naunyn Schmiedebergs Arch Pharmacol 377: 333-343.

18. Yu AL, Ahluwalia GK, Goldfarb S, Forman JP (2012) Evaluation and treatment of hypomagnesemia. 